\title{
Miranda
}

Revue pluridisciplinaire du monde anglophone /

Multidisciplinary peer-reviewed journal on the English-

speaking world

$21 \mid 2020$

Modernism and the Obscene

\section{Disinterest and Disruption: The Picture of Dorian Gray and the Modernist Aesthetics of the Obscene}

\section{Kevin Kennedy}

\section{OpenEdition}

\section{Journals}

\section{Electronic version}

URL: http://journals.openedition.org/miranda/27718

DOI: 10.4000/miranda. 27718

ISSN: 2108-6559

Publisher

Université Toulouse - Jean Jaurès

\section{Electronic reference}

Kevin Kennedy, "Disinterest and Disruption: The Picture of Dorian Gray and the Modernist Aesthetics of the Obscene", Miranda [Online], 21 | 2020, Online since 09 October 2020, connection on 16 February 2021. URL: http://journals.openedition.org/miranda/27718; DOI: https://doi.org/10.4000/miranda. 27718

This text was automatically generated on 16 February 2021

\section{(c) $(1)$}

Miranda is licensed under a Creative Commons Attribution-NonCommercial-NoDerivatives 4.0 International License. 


\title{
Disinterest and Disruption: The Picture of Dorian Gray and the Modernist Aesthetics of the Obscene
}

\author{
Kevin Kennedy
}

More than this, it is easy to imagine a book, let us say, by Oscar Wilde, clever, scintillating, even brilliant in its writing and utterly foul and disgusting in its central theme and dominating effect. ${ }^{1}$

1 Derived from the Latin obscenus, whose etymology is sometimes traced back to the notion of an offstage or hidden area, the obscene is situated at the limits of representation, disrupting conventional notions of morality and art. $^{2}$ It has been argued that modernist fiction is based on an aesthetics of the obscene (Pease 2000), fundamentally breaking with the Kantian notion of aesthetic disinterestedness, which had dominated most of the $19^{\text {th }}$ century. While the latter foregrounds contemplation and the communal, sublimated aspects of bodily experience, modernism de-sublimates the body, emphasizing its sensual, filthy, anti-social, abject dimension. In its apparent commitment to aestheticism and late-Victorian decadence, Oscar Wilde's fin-de-siècle novel The Picture of Dorian Gray is not usually subsumed within the modernist canon. Yet, like many notable modernist novels, it was accused of obscenity and virtually banned, despite all the supposedly obscene acts taking place "offstage," intimated only through allusion. In its ironic portrayal of the corrupting influence of art, Wilde's novel prefigures (and to some extent even exceeds) the way in which so-called obscene art will be treated in the legal, academic and social discourses of the first part of the twentieth century. In the following, I intend to explore to what extent Wilde's novel can be considered a proto-modernist text in its adherence to an "aesthetics of obscenity" and its rejection of Kantian disinterestedness. I argue that Dorian Gray, while not explicitly describing taboo acts like modernist works such as Ulysses, is modernist in its attempt to introduce the un-sublimated body into the realm of high art. My discussion will focus on Wilde's exploration of the tension between the body and aesthetic representation, which in the novel is symbolized by its two main characters, Dorian and Lord Henry, and literalized through the painting that records Dorian's 
"obscene" acts. I suggest that its meta-commentary on the relation between obscenity and the aesthetic, corruption and morality, makes Wilde's novel a paradigmatic modernist text. In conclusion, I analyse the nature of the obscene, which, as I argue, is not necessarily the explicit depiction of bodily functions or sexual acts, but the "thing" that ultimately resists representation, remaining "offstage," frustrating any attempt at appropriation and thus disrupting the basic parameters of social and subjective existence.

\section{Wilde and Obscene Modernism}

2 The obscene has long been associated with literary modernism and its various formal and thematic transgressions. In recent years, there has been a plethora of articles and books on the legal, aesthetic, moral and formal dimension of obscene literature at the beginning of the twentieth century, establishing it as a defining feature of modernist art as a whole (see, for instance, Pease 2000, Pagnattaro 2001, Glass 2006, Potter 2013): "Modernist art is produced at the same historical moment and in the same social space as 'obscene' art" (Chisholm 167). While Victorian and fin-de-siècle authors are sometimes discussed as important precursors to this "aesthetics of the obscene," Oscar Wilde is only rarely mentioned in this context. Although his work is often seen as sharing and even heralding many key concerns of literary modernism, such as his interest in aesthetic autonomy, individualism and formal experimentation (Gagnier 1997), it is only occasionally analysed in relation to its obscene dimension. Wilde's credentials as a transgressive artist, however, are well established. Jonathan Dollimore discusses Wilde's "transgressive aesthetic" in relation to his radical individualism and (homo-)sexuality (Dollimore), while Petra Dierkes-Thrun argues that Salomé (which she construes as a paradigmatic modernist text) partakes in the modernist "replacement of traditional metaphysical, moral, and cultural belief systems with literary and artistic discourses that develop utopian erotic and aesthetic visions of individual transgression" (Dierkes-Thrun 2).

3 In addition to its transgressive modernism, Wilde's work has also been discussed in the context of the legal and moral issues surrounding obscene literature in the late $19^{\text {th }}$ century. Simon Stern analyses the "Obscenity Effects" of Wilde's seminal novel The Picture of Dorian Gray, yet without specifically linking it to the discourse on obscene modernism, so prevalent in recent modernist studies. Stern's article compellingly shows how the novel dissects the dialectic of corruption and autonomy that underlies the prosecution of obscene works: "Wilde interweaves questions of influence, corruption, and addiction-and at the same time [...] retraces the logic by which jurists and legislators purported to diagnose the agency of obscene works" (Stern 762). This notion of corruption was most famously expressed in the so-called Hicklin test from 1868, which became the legal benchmark for judging obscene literature for almost a century, shaping the majority of legal cases involving modernist works in the early 1900s. According to Hicklin, a work was deemed obscene if it had the tendency "to deprave and corrupt those whose minds are open to such immoral influences, and into whose hands a publication of this sort may fall." (quoted in Pagnattaro 218) This almost reads like a summary of The Picture of Dorian Gray, whose eponymous protagonist starts leading a life of "sin" after reading an obscene work of literature, the so-called Yellow Book: "Dorian Gray had been poisoned by a book" (Wilde 2000, 140). Dorian is thus 
presented as the stereotypical untrained reader-naïve, gullible and lacking any will or discernment of their own-whom the prosecutors of obscene works set out to protect: "Dorian presents a thoroughly ironized portrait of a young person complying with the predictions of the obscenity police" (Stern 762). In addition to young people, the law sought to inoculate women and the increasingly literate working-class population, i.e., segments of the population, whose enfranchisement was seen as a potential threat to the dominant political order. ${ }^{3}$ Wilde's critical and satirical portrayal of the corrupting influence of art thus already intimates the political dimension underlying the seemingly moral question of whether a particular person should be exposed to certain works or not, presaging "the next century's struggle with perennial questions about art and its responsibilities to and freedom from its reading audience" (Leckie 172).

Prosecutions for obscenity of famous modernist works, such as Ulysses or Lady Chatterley's Lover, likewise often hinged on a distinction between the (literary) elitewhose education and intellectual powers would shield them from a work's damaging influence-and the average readers-whose lack of training and/or mental incapacity would render them highly susceptible. The defenders of "obscene" modernist literature, by contrast, shifted the focus away from the content to the work itself, foregrounding its autonomy and artistic integrity: "The belief that art's claim for value and for our serious attention rests not on its ideas, message, or content, but on aesthetic considerations divorced from subject matter stands at the center of the revolution that we call modernism" (McGowan 417). Again, this stance is already explored in Wilde's novel, especially by the famous "Preface", which states that "There is no such thing as a moral or an immoral book. Books are well written, or badly written [...] Vice and virtue are to the artist materials for an art" (Wilde 2000, 3-4). Wilde's preface, added for the novel's second edition, was written in response to the accusation of immorality and obscenity levelled at the text upon its initial publication. Although it is never made explicit what kind of "sinful" activity Dorian Gray engages in, many contemporary readers thought it contained coded references to sodomy, which at the time was still a crime. ${ }^{4}$ Akin to the defence of Ulysses thirty years later, Wilde's preface defends his use of "obscene" material by appealing to the aesthetic value of his work, radically divorcing it from its ethical content, demanding a space for art where "The artist can express everything" (3). This mirrors the "obscenity of modernism," which, as Loren Glass observes, "was contained by its aesthetic consecration. The Ulysses case provided legal sanction for this space of containment" (Glass 349). Wilde's novel thus already contains in nuce the shift from a vision in which the literary work is defined both by its contents and its ethical relation with an implied audience, towards a vision in which literature is defined by its autonomy, which characterised the literary obscenity trials and debates of the first part of the $20^{\text {th }}$ century.

With the end of the prosecutions of obscene works of art in the second half of the $20^{\text {th }}$ century, the focus shifted yet again, this time away from the "autonomous qualities of texts to the phenomenological experience of readers" (Glass 357). In tandem with the transition towards a more democratic, inclusive society following World War II, the law no longer felt the need to protect certain segments of the population, passing the responsibility of how to respond to morally questionable literature on to the reader. The emphasis on the individual's role when dealing with obscene literature is again prefigured in Wilde's novel when he claims that "It is the spectator, and not life, that art really mirrors" (Wilde 2000, 4). The novel itself illustrates this point by highlighting the way Dorian responds to the different works of art in his life, the painting and the 
Yellow Book, both of which he blames for his moral failings. Wilde makes it clear that art, regardless of how obscene or transgressive it is, can never be held accountable for an individual's actions. Lord Henry, echoing Wilde's own views, expresses it most succinctly: "As for being poisoned by a book, there is no such thing as that. Art has no influence upon action [...] The books that the world calls immoral are books that show the world its own shame" (208). The Picture of Dorian Gray's call for an aesthetically autonomous appreciation of art thus functions as a harbinger of how the question of obscene art would be dealt with in the era of literary modernism and beyond: "The aesthetic argument [...] anticipates the most successful response to print censorship that would develop in the modernist period. Instead of highlighting the need to protect the reader, the emphasis slowly shifted to the need to protect art" (Leckie 174).

6 There is, however, a more specific sense in which Wilde's novel may be put into a productive dialogue with obscene modernism, particularly regarding questions of aesthetic disinterest, the disruptive potential of art and the often only implicit political dimension underlying them, beyond the legal framework in which such discussions are usually couched, and which tend to unduly restrict them. "Questions concerning the artistry of obscenity and the reading of art for nondiscursive modes of transgression are often lost in the discussion of the strategies and effects of legalization" (Chisholm 167). In the following I will discuss The Picture of Dorian Gray in relation to some key aspects of Allison Pease's influential work Modernism, Mass Culture and the Aesthetics of the Obscene, which presents questions of artistic obscenity in a larger sociohistorical and philosophical context, beyond their strictly legal interpretation.

\section{Disinterest, Disruption and the Aesthetics of Obscenity}

7 Pease argues that the modernist "aesthetic of the obscene," which emerged in the early $20^{\text {th }}$ century, is based on a conflation of two different modes of representation, which in the $19^{\text {th }}$ century had been strictly separated: aesthetics and pornography. Pease differentiates these two modes using Kant's famous distinction between the agreeable and the beautiful (Kant 51-53). Although both ultimately derive from the body, the agreeable is aimed directly at an individual's sensual satisfaction (e.g. food, sex, alcohol), while the beautiful in the Kantian sense transcends physical pleasure, becoming a communal category of taste. Thus "the subject of the agreeable has an interest in that agreeable object. The subject of the beautiful is [...] disinterested" (Pease 22). Pease construes pornography as a prime example of the agreeable. Unlike high art, pornographic literature offers an unmediated representation of the (sexual) body, having "arousal as its main purpose" (34), i.e., aiming at private pleasure. For Pease, the pornographic is thus associated with "interest, individualism, and social disruption" (164). Traditional aesthetics, à la Kant or Shaftsbury, by contrast, are an attempt to transform physical sensation into a rational category, whereby sense becomes idea, the private becomes communal/communicable, the agreeable becomes beautiful, and the body's irrational, disruptive materiality is disciplined.

8 The Picture of Dorian Gray reflects the tension between mind and body, disinterest and interest, as elaborated in Pease's notion of the obscene aesthetics of modernism on both a thematic and a formal level. As has been noted by many commentators, Wilde's novel is full of references to the physical body and its complicated relationship with the 
mind (see for example Davis 2013). In a very general sense, it may be read as an attack on the strict separation between sensuality and rationality, characteristic of $19^{\text {th }}$ century aesthetics. "The harmony of soul and body,-how much that is! We in our madness have separated the two, and have invented a realism that is bestial, an ideality that is void" (Wilde 2000, 13). Yet, at the same time, it very much continues the aesthetic tradition of artistically sublimating obscene or explicit representations of the body, of "spiritualizing the senses" (126), rejecting any form of crass realism and, by implication, pornography. In this sense it is continuous with "the earlier project of Shaftsburian and Kantian aesthetics to bring the body more overtly into the realm of culture by objectifying the senses and making them rationally intelligible" (Pease 38). This is also reflected in Dorian Gray's depiction of class.

9 Pease shows that the aesthetic disavowal of the body through an engagement with art is based on specific class considerations. One of the key ideological categories informing the property-owning bourgeoisie's claim to superiority was the notion of "disinterestedness," based on "economic and aesthetic distancing" (24). Its political power was legitimate, so the argument went, because it was economically independent, free from the narrow material interests of the masses and thus able to judge impartially and justly. This freedom from economic considerations was complemented by an assumed freedom from the demands of the physical body. A gentleman's position of power and influence was thus justified because he, unlike the majority of people, was not under the constraints of physical passions and base economic interests. Hence the prevalent attempt in $19^{\text {th }}$ century philosophy, which in many ways functioned as an ideological justification for the political status quo, "to stave off the forces of interest, desire and irrationality from a pure sphere of understanding" (25). The aesthetic (and by implication the whole political) ideology of the $19^{\text {th }}$ century middle classes in Europe was thus one of disembodiment and disinterest.

10 Conversely, the "interested" body came to be seen as a threat to order and social stability: it became an obscene, morally questionable body-vulgar, sensual, possibly diseased-, which had to be policed, purified and proscribed. It thus emerged as a central, albeit negative, category of middle-class self-definition, both literally and metaphorically. Everything that was excluded from the self-understanding of the educated middle classes became associated with the body: women, "exotic" peoples, criminals, and especially the working classes. In a dominant political metaphor of the time, the latter was regarded as the body to the middle-class mind, which, like the real body, had to be tamed and subdued, lest its unruly nature would cause chaos and disruption: "To the middle classes the working classes represented the body, and as such were outside the culturally hegemonic realm (while simultaneously functioning as a necessary other, as necessary as one's own body)" (77).

11 Like many novels of its time, The Picture of Dorian Gray displays the anxieties of the educated middle and upper classes towards the working population and the erosion of traditional class structures at the end of the $19^{\text {th }}$ century, explicitly linking the body with the lower strata of society. The dandified lord and quintessential aesthete Lord Henry claims that "crime is to lower classes what art is to us, simply a method of procuring extraordinary sensations" (Wilde 2000, 202), suggesting that the different classes have different ways of satisfying physical needs: unmediated, individual, interested (financial, sexual) satisfaction, on the one hand, and sublimated, disinterested aesthetic enjoyment, on the other. Although Wilde championed an equal 
and democratic society, ${ }^{5}$ his values were very much those of the aristocracy. The values of the Aesthetic movement, of which Wilde was a major exponent, were a "relic of the anti-materialist, aristocratic ideals of the $18^{\text {th }}$ century which were perpetuated by an elite educational system that tried to cut itself off from the means of production" (Pease 46). Pease argues that this attitude was based on a fundamental paradox, as the aristocratic and middle-class elites were only able to create a coherent image of themselves in relation to what they condemned: "vulgar" material interests, the increasing commercialization and industrialization of social life and, most importantly, the obscene body. Thus, with the gradual enfranchisement of the working classes, "the ideological boundaries of privilege were being threatened by the very bodies that had been needed to define privilege itself" (43).

Wilde's portrayal of the well-do-to elites in Dorian Gray frequently relies on foils from the working-class population. ${ }^{6}$ At one point, Dorian is contrasted with the frame-maker Mr Hubbard, who carries the eponymous painting up to its hiding place in the attic, while Dorian looks on. The narrator describes Hubbard as having "the true tradesman's spirited dislike of seeing a gentleman doing anything useful" (Wilde 2000, 117). Conversely, towards the beginning of the novel Lord Henry's uncle, Lord Fermor, is characterized in terms of his disdain for work and utility, having

[...] set himself to the serious study of the great aristocratic art of doing absolutely nothing[...] he paid some attention to the management of his collieries in the Midland counties, excusing himself for this taint of industry on the ground that the one advantage of having coal was that it enabled a gentleman to afford the decency of burning wood on his own hearth (33).

Wilde thus integrates and perpetuates the dominant class ideology of his time, drawing a sharp dividing line between those who have to use their "obscene" bodies to survive and those who disparage any form of physical labour. However, despite its professed attitude towards class, Wilde's novel also prefigures some of the socially disruptive elements that would come to characterize modernist literature, specifically in its confrontation between physical passion, on the one hand, and its aesthetic, rational sublimation, on the other.

In the early $20^{\text {th }}$ century, many modernist writers began to explore the disruptive potential of the body, radically changing and expanding the possibilities and moral parameters of art. Several writers, such as James Joyce and D.H. Lawrence, incorporated pornographic tropes into their writing. Thus, according to Allison Pease, "the body entered art, and quite specifically literary art" (Pease 192). However, in contrast to traditional pornography, which, as we have seen, is aimed at physical stimulation and thus fundamentally "interested," the modernist aesthetic of the obscene "is a mode of sexual representation that, while potentially affecting the sensual interests of its readers, does not, as opposed to pornography, seek sexual arousal as its main purpose" (34). Pease's key point is that even though the modernists revolutionized literary representation, defying the moral censorship of the body, they ultimately continued the aesthetic tradition by subordinating physical stimulation to intellectual contemplation: "the aesthetic of the obscene continues to objectify and distance the senses, and in doing so it perpetuates the project of the aesthetic traditions" (35). In other words, although modernism embraced the disruptive potential of the body, it ultimately absorbed and diluted this disruption within aesthetic disinterest.

The modernist approach to obscene material thus rested on a basic paradox. In its attempt to capture "individual sensual impact that cannot necessarily be universally 
communicated" (35), it repudiated the universal aspirations of traditional aesthetics. Yet, in bringing the body into the realm of high art, it attempted to universalize the very negation of universality, which characterizes the obscene. I would argue that this very paradox is also present, albeit in a slightly less explicit form, in Wilde's The Picture of Dorian Gray, exemplified by its two main characters, Lord Henry and Dorian Gray.

\section{Lord Henry and the Aesthetic Disavowal of the Body}

Lord Henry's flamboyantly amoral pronouncements and witticisms have already been discussed abundantly in the available secondary literature. ${ }^{7}$ The same is true for the seemingly immoral influence he exerts on the young and impressionable Dorian. ${ }^{8}$ As Patrick Duggan notes, "Lord Henry Wotton trumpets the aesthetic philosophy with an elegance and bravado that persuade Dorian to trust in the principles he espouses; the reader is often similarly captivated," but, and I would agree with this claim, "it would be a mistake [...] to interpret the novel as a patent recommendation of aestheticism" (Duggan 61). The Picture of Dorian Gray is often seen as a prime example of Aestheticist literature, in which the two main characters-whose friendship is more like a teacher and student relation-live, think and act according to Aestheticist principles. Yet, their respective attitudes towards life and art are in fact quite dissimilar, to the point of being mutually exclusive. Using the aforementioned tension between the Kantian notions of the agreeable and the beautiful, or, in Pease's terms, the pornographic and the aesthetic, it becomes possible to argue that Lord Henry is not really a full-blown aestheticist, but rather a Kantian aesthete, whose main concern is to translate sensual experience into disembodied, communal pleasure. Dorian, on the other hand, is identified with selfish, interested, obscene sensuality, whose experiences therefore resist communal (and even linguistic) appropriation and who therefore negates the aesthetic philosophy espoused by his mentor. In this sense, one might say that in the novel, taken as a whole, Dorian functions as the obscene body to Henry's "disembodied" mind.

Although Lord Henry ultimately continues the Kantian tradition of negating body in favour of mind, he nonetheless rejects any strict dualism: "Soul and body, body and soul-how mysterious they were! There was animalism in the soul, and the body had its moments of spirituality. The senses could refine, and the intellect could degrade. Who could say where the fleshly impulse ceased, or the psychical impulse began?" (Wilde 2000, 57). And, a little earlier, he claims that "Nothing can cure the soul but the senses, just as nothing can cure the senses but the soul" (23). This deliberate equivocation concerning the hierarchy of mind and body is the reason why Lord Henry is usually seen as the quintessential Aestheticist, who calls for a "new hedonism" (25), an amoral approach to life and art, in which pleasure should always trump conscience. On the surface, this reading is certainly warranted, as the following passage nicely illustrates, where Henry is trying to impress Dorian with a proto-Freudian speech about inhibition and release:

I believe that if one man were to live his life out fully and completely, were to give form to every feeling, expression to every thought, reality to every dream,-I believe that the world would gain such a fresh impulse of joy that we would forget all the maladies of mediaevalism[...] Every impulse that we strive to strangle broods in the mind, and poisons us. The body sins once, and has done with its sin, for action is a mode of purification. Nothing remains then but the recollection of a 
pleasure, or the luxury of a regret. The only way to get rid of a temptation is to yield to it. (21) concerned with words than with deeds, with bodiless pleasure than with carnal satisfaction. As his painter friend Basil Hallward tells him: "You never say a moral thing, and you never do a wrong thing. Your cynicism is simply a pose" (8). Lord Henry is a popular socialite, a favourite guest at the all the dinner tables of London's upperclass society, where he charms his hosts with his pointed remarks and witty paradoxes. Although he constantly provokes and teases his various interlocutors with speeches on uninhibited sensuality and society's "monstrous laws" (21) that suppress it-at one point even asserting that "sin is the only real colour element left in modern life" (30)it quickly becomes clear that what he is really interested in, is not so much experiencing "new sensations" (25), but talking about them. As he admits himself at one point: "One's own soul and the passions of one's friends-those were the fascinating things in life" (15): in other words, what he really wants is to aesthetically appropriate the physical passion of others (like Dorian Gray, for example). His real concern is to "give lovely names to things. Names are everything" (186). And, in what could be described as an attack on the obscene aesthetics of modernism avant la lettre, he professes to "hate vulgar realism in literature. The man who could call a spade a spade should be compelled to use one. It is the only thing he is fit for" (186). In one witty epigram, he thus continues the traditional upper-class amalgamation of explicit (bodily) representation and physical labour, both of which he sneers at.

Lord Henry ultimately disavows the obscene, sensual body in favour of gentlemanly distance and detachment, thus subscribing to and upholding the aesthetic tradition of $19^{\text {th }}$ century philosophy, "based on a lack of bodily need, a disavowal of desire, control over objects through cognitive distance, and a belief in the possibility of universal consensus in the experience of the beautiful" (Pease 27). Henry abhors the "vulgar" details, which, in his mind, should always be aesthetically transformed into beauty and harmony: "One should absorb the colour of life, but one should never remember its details. Details are always vulgar" (Wilde 2000, 98). In a similar vein, he laments that he lives in "an age so grossly carnal in its pleasures, and grossly common in its aims" (37). Channelling the values of his class, he associates physicality with the common man, whom he implicitly chides for his "crude violence [...] lack of style [...] vulgarity[...] and sheer brute force" (98). The clearest indication, however, that Lord Henry is not a depraved Sadean libertine, willing to take any risk in order to procure extraordinary sensations, comes towards the end, when he tells Dorian that "murder is always a mistake. One should never do anything that one cannot talk about after dinner" (203). This amounts to an exemplary (albeit humorous) Kantian denigration of the body (murder is one the most violently "interested" actions possible) and a plea for all physical activities to become universally, socially communicable, integrated into the prevailing conventions of taste and morality, in this case the post-dinner chat of refined gentlemen over cigars and brandy. 


\section{Dorian Gray and the Interested Body}

21 In stark contrast to Lord Henry's insouciant provocations, turning (reported) private transgression into public pleasure, his protégé Dorian Gray ultimately abandons the public realm in favour of private sensuality and experience. In this respect, Dorian is reflective of a shift that Kathy Alexis Psomiades associates with the transgressive poetry of Algernon Swinburne, one of Pease's exemplary Victorian precursors to the modernist aesthetics of the obscene: "Instead of marking the moment when beauty becomes public, it marks the moment at which public man is privatized, drawn into the aesthetic erotic realm, and at which he gives up his public power for private pleasure" (Psomiades 87). Dorian is drawn into the "erotic realm" because he decides to put the things that Lord Henry talks about "into practice, as I do everything you say" (Wilde 2000, 47). It is true that Wilde never explicitly describes the transgressive practices Dorian engages in-even though their carnal nature is strongly implied. In this sense his work is fundamentally different from the explicit descriptions of body parts and sexual acts in "obscene" modernist works such as Ulysses. However, as Pease suggests, the explicit representation of the body is not essential to the modernist aesthetic of the obscene; the fact that the works she puts forth as exemplars of obscene modernism "contain explicit sexual representations simply makes the incorporation of the body into artistic representational and reception practices more obvious" (Pease 192).

On the one hand, it is clear that Dorian, because of his "extraordinary good looks" (Wilde 2000, 101), symbolizes classical physical beauty: ethereal, refined and chaste. Yet, as the narrative progresses, he becomes increasingly associated with the "other" body (obscene, indescribable, disruptive) and all of its contemporary metaphorical connotations: deviant sexuality and low social status. Dorian continually strives for new physical sensations: "infinite passion, pleasures subtle and secret, wild joys and wilder sins-he was to have all of these things" (102). Eschewing detailed description, Wilde frequently resorts to the Christian notion of sin to delineate Dorian's behaviour. Yet, he completely empties it of its traditional metaphysical sense as a violation of divine law, linking it quite explicitly with physical passion, beyond conscious control: "There are moments, psychologists tell us, when the passion for sin, or for what the world calls sin, so dominates [...] every fibre of the body [...] Men and women at such moments lose the freedom of their will. They move to their terrible end as automatons move" (181). The implication is that, when Dorian pursues his secret passions, he becomes pure body, devoid of will, reason or conscience.

Although seemingly in thrall to Lord Henry's teachings, which promote a more or less traditional hierarchy between body and mind, Dorian constantly subordinates the mind to the body, and theory to experience: "he felt keenly how barren all intellectual speculation is when separated from action and experiment" (128). The "new hedonism" he envisions "was to have its service of the intellect, certainly; yet it was never to accept any theory or system that would involve the sacrifice of any mode of passionate experience" (126). At one point, Dorian even becomes interested in contemporary biological accounts of human agency, "delighting in the conception of the absolute dependence of the spirit on certain physical conditions, morbid or healthy, normal or diseased" (128). Dorian's delight in this biological dependence of mind on "morbid" physicality could not be further from Lord Henry's categorical rejection of vulgar 
details. Dorian, in his rejection of sublimated, aestheticized passion, thus represents the pornographic, interested body, in love with "things that one can touch and handle" (107). For the effect of pornography, as Pease writes, "is such that it registers decidedly individual sensual impact that cannot necessarily be universally communicated. In this way it promotes a turning inward of the subject" (Pease 35). Likewise, Dorian is concerned with private sensation and sensual gratification, which resist sublimation and thus need to remain unarticulated.

Dorian is gripped by "passions that would find their terrible outlet" (Wilde 2000, 115), yet he is unable to communicate his experiences to society at large, because polite society rejects the body. He fills other people with "a madness for pleasure" (145), ruining reputations and giving rise to wild speculations about his activities: "His extraordinary absences became notorious, and, when he used to reappear again in society, men would whisper to each other in corners...determined to discover his secret" (136). Basil Hallward fears that Dorian is "bad, corrupt and shameful" (147), but Dorian is convinced that society is merely hypocritical: "we are in the native land of the hypocrite" (146). Yet, at the same time, he lives in the constant fear that "the world would know his secret" (135), i.e., the secret of the body, in its pure, unmediated materiality. He spends long, solitary hours gazing at the "obscene" painting (variously described as "bestial, sodden and unclean" (118), "shameful" (115) and having "a corruption of its own"(115)) like a stereotypical consumer of pornography. The tragedy of his character, however, is his ultimate inability to grasp the fact that he "is" the body. He constantly mocks the painting for its "misshapen body and the failing limbs" (124), failing to make the inextricable connection between the self and its physical manifestation. After murdering Basil Hallward, he blackmails his former friend Alan Campbell into making the body disappear, because it "is the only piece of evidence against me" (162). Yet, in his final attempt to rid himself of his own body, symbolized by the painting, he inadvertently kills himself, confirming the inextricable tie between his character and the "shameful body".

While the protagonist of The Picture of Dorian Gray symbolizes the literal body, he is also associated with the body in a more metaphorical sense, specifically with the workingclass body, reflecting the widespread association of the lower classes with pornography, both of which were regarded as fundamentally disruptive: "the lower classes and pornography were viewed as uncontrollable, diseased, or poisonous forces that threatened to penetrate the healthy social body" (Pease 49). Unlike Lord Henry, Dorian is the product of a class-transcending liaison. His aristocratic mother marries "a penniless, young fellow, a mere nobody" (Wilde 2000, 35), leading to her social ostracization and early death. As the narrative progresses, London's working-class areas, its brothels and opium dens, become Dorian's favoured hunting ground: "I felt that this grey, monstrous London of ours, with its myriads of people, its splendid sinners, and its sordid sins [...] must have something in store for me" (48). Utilizing a common narrative trope of Victorian literature, Wilde has Dorian visit the East End, where "it was said that he had been seen brawling with foreign sailors in a low den in the distant parts of Whitechapel, and that he consorted with thieves and coiners and knew the mysteries of their trade" (136). There his fascination with the obscene body is made explicit: "The twisted limbs, the gaping mouths, the staring lustreless eyes, fascinated him" (179). Yet, at the same time, he is reminded of Lord Henry's words that 
"you can only cure the soul by means of the senses", which "he had often tried[...] and would try [...] again now" (176).

Although Dorian strives for a "spiritualizing of the senses" (126), for the aesthetic sublimation of base physical needs, he ultimately fails "to stave off the forces of interest, desire and irrationality from a pure sphere of understanding" (Pease 25). Towards the end of the novel he wholeheartedly embraces the interested, obscene body, fundamentally breaking with Lord Henry's Kantian aestheticism, the redeeming qualities of art, as well as its underlying class ideology:

Ugliness that had once been hateful to him because it made things real, became dear to him now for that very reason. Ugliness was the one reality. The coarse brawl, the loathsome den, the crude violence of disordered life, the very vileness of thief and outcast, were more vivid, in their intense actuality of impression, than all the gracious shapes of art, the dreamy shadows of song (177-178).

Dismissing ethereal, "dreamy" art and celebrating "coarse" reality, Dorian rejects both Aestheticism and traditional Kantian aesthetics, in the same way that, according to Pease, modernist literature subverted traditional standards of representation by including unfiltered, graphic depictions of sexuality. Dorian's character is thus reflective of Wilde's attempt to introduce the interested body into the realm of high culture. The paradox here, however, is that Dorian's praise of the chaotic, vulgar, unmediated world of social outcasts, perverts and criminals ("the crude violence of disordered life") occurs in a highly stylized, high-cultural format. Thus, like his fellow proto-modernist Swinburne, and in contrast to actual pornographic literature, Wilde makes the "body safe for middle class consumption" (Pease 63-64), for whom obscenity is "socially problematic because of its potential to disrupt community" (5). ${ }^{9}$ In other words, by including the obscene body into a work of high art, he "removes from the body its threatening materiality" (71). Despite his own programmatic claim in "The Soul of Man Under Socialism' that "Art is Individualism and Individualism is a disturbing and disintegrating force" (Wilde 2007, 254), Wilde's treatment of the individual, sensualized body, like that of his modernist successors, ultimately subsumes disruptive jouissance within aesthetic enjoyment, turning the body into an object for communal, sublimated contemplation, "no longer solely obscene, or offensive to taste" (Pease 35).

\section{Conclusion: The Obscene Resistance to Representation}

The tension between the interested body and disinterested contemplation, which, according to Pease, lies at the heart of obscene modernism, also fundamentally shapes The Picture of Dorian Gray. In this respect, it belongs to the tradition inaugurated by such quintessential modernists as Nietzsche, Freud and Marx and their respective projects of rehabilitating the body against the aesthetic tradition of the $19^{\text {th }}$ century. Conversely, like many works of high modernist fiction, Wilde's novel attempts to bring the agreeable into the realm of the beautiful, private pleasure into disinterested art. This is nicely reflected in Lord Henry's attempt, towards the end of the narrative, to aestheticize Dorian's (obscene) existence/body, telling him that "life has been your art. You have set yourself to music. Your days are your sonnets" (Wilde 2000, 207). Of course, The Picture of Dorian Gray contains no explicit sexual representation, only hints and allusions, and in this sense fundamentally differs from high modernist works. 
However, these allusions were seemingly enough to provoke outrage and disgust in its contemporary readers. One review, for instance, claimed that the book "derives pleasure from treating a subject merely because it is disgusting" and "delights in dirtiness and confesses its delight" (216). To its contemporary readers, The Picture of Dorian Gray thus undoubtedly contained an obscene, fundamentally interested dimension.

This disgust at an invisible obscenity, as opposed to an explicit representation, points towards an under-theorized dimension of obscenity in recent modernist studies. This dimension, as I would suggest, accounts for the fundamentally disruptive nature of obscene material, beyond the private pleasure of an anti-social individual or the fear of class erosion. Discussing the work of D.H. Lawrence, Rachel Potter argues that "the obscene specifically signifies ideas about the limits of knowledge [...] the desire to label the object as obscene...is an attempt to place and contain it; to control the strangeness of it and its ability to disturb" (Potter 115). This suggests that the obscene representation always points towards an unknown, frightening realm, where the distinctions that structure everyday reality (body/mind, word/object, inside/outside, aristocrat/worker, judge/criminal) collapse. In other words, obscenity functions as a linguistic strategy to bring that which lies outside the accepted standards of representation into the realm of symbolization, thereby attaining a degree of control over it. In this sense, it is like the Lacanian Real, an attempt to think "pure" materiality before its transposition into meaning and signification (cf. Lacan 1998). The Real, like the obscene, points towards the beyond of langue, beyond the ineluctable universality and transparency of the (written) word. As Hal Foster suggests, "'Obscene' does not mean 'against the scene' but suggests an attack on the scene of representation [...] an impossible opening onto the real" (Foster 113-114). The obscene is impossible because, in its attempt to label and control the "beyond" of representation, it merely illustrates the absence of "real" matter, "real" bodies and "real" pleasure in the immateriality of language: the obscene, like the Real, can never be accessed directly, since it is only produced through its own absence.

The Picture of Dorian Gray stages, and grapples with, the impossibility of communicating the "secret" physicality of bodily experience. It is full of references to secrecy and secret vices, refusing to be captured within the transparency and stability of a fixed term, phrase or image: "those curious unpictured sins whose very mystery lent them their subtlety and their charm" (Wilde 2000, 118). Wilde struggles to convey the unthinking fleshliness, the pure, unmediated physicality of the body. Dorian, for example, is touched by a "secret chord, that had never been touched before, but that he felt was now vibrating and throbbing to curious pulses" (21). Setting off for the East End, he is in search of that "poisonous secret of life" (237), as well as "pleasures subtle and secret" (102). The absence of explicit representation in Wilde's novel is not solely due to concerns over public decency or the fear of prosecution. Rather, Wilde is convinced that "the crude brutality of plain realism" (Wilde 1962, 264) is unable to capture the secret, mute, "offstage" dimension of existence itself. ${ }^{10}$ As so often in the novel, Wilde uses Basil Hallward as a foil for his own ideas. The latter is convinced that obscene "vices" ultimately become legible on the body, visible and transparent: "People talk sometimes of secret vices. There are no such things. If a wretched man has a vice, it shows itself in the lines of his mouth, the droop of his eyelids, the moulding of his hands even" (Wilde 2000, 143). Wilde, however, is fully aware that as soon as one 
theorizes sensual experience, one is immediately in the realm of language and human cognition and thus inevitably fails to capture the experience in question. Sinful bodies are linguistic constructs, whose true "reality" must therefore always remain a secret. His novel thus bears testament to the more general "difficulty of translating being into knowing" (Pease 145), formlessness into form, objects into words: "Mere words! How terrible they were! How clear, and vivid, and cruel! One could not escape from them. And yet [...] They seemed to be able to give a plastic form to formless things [...] Was there anything so real as words?" (Wilde 2000, 22).

The novel's poetics of allusion are crystallized in Wilde's persistent use of the word "thing", the most generic word in the English language ("formless things" (22), "things that one can touch and handle" (107) "it made things real" (177), "to have all of these things" (102), "give lovely names to things (186), "You never say a moral thing, and you never do a wrong thing". (8) "the fascinating things in life" (15)). ${ }^{11}$ This is evidently not due to Wilde's lack of verbal dexterity, but rather suggests an attempt on his part to designate a reality beyond words, as featureless and undefined as the word "thing" itself. The word "thing" furthermore recalls Kant's 'thing-in-itself, the noumenal reality beyond phenomena, which, according to Kant, always escapes mediation and thus cognition. The "thing's" resistance to representation, its essential "off-stageness," is reflected in the tension between surface and depth (appearance/truth, body/soul, phenomenon/noumenon) that structures Wilde's novel. ${ }^{12}$ The numerous allusions to secret depths and invisible realms, which lie behind the surfaces of "things", attest to a preoccupation with phenomena that resist straightforward symbolization. Thus, the preface programmatically states that "all art is at once surface and symbol/ Those who go beneath the surface do so at their peril" (Wilde 2000, 4). The beyond of representation is perilous because it is-as Dorian remarks vis-à-vis music (the nonrepresentational art par excellence)-"not articulate. It was not a new world but rather another chaos, that it created in us" (29). As Anna Budziak suggests, "metaphorical depth means 'chaos'; it cannot be explored since all meaning is always exposed on the 'surfaces”' (Budziak 138).

Through Dorian, Wilde explores the fascination exerted by elusive depths, beyond mediation, while intimating that they will only ever yield unintelligible confusion. Dorian is worried that he is shallow (Wilde 2000, 49), devoid of depth, failing to realize that, as Lord Henry observes in one of his faux-didactic monologues, one must remain faithful to the surface (of representation) as there ultimately is nothing behind appearance: "It is only shallow people who do not judge by appearances" (24). Dorian's downfall is precipitated by his belief in metaphysical depth, the soul behind the body, represented by the painting. Before showing Basil the painting, he proclaims "I shall show you my soul" (146). For him, "the soul is a terrible reality" (205), i.e., he thinks of noumenal depth as substantial and real, as clear and legible as a portrait. However, when Dorian attempts to destroy the portrait "its surface-though in the most uncanny way-remains intact [...] The meaning, thus, is to be read on the flat surface, whilst the bodies, even if treated as a metaphor of enclosure for their three-dimensionality and alleged depth, having been rendered open by stabbing, reveal no deep essence of their lives" (Budziak 140). The obscene body in Wilde's novel thus remains as mute and uncommunicative as the Kantian "thing-in itself," while nonetheless persisting in its very inarticulability. 

etymological sense, as that which remains "offstage", beyond representation, beyond words-not because of its questionable morality, but because of its inherent unrepresentability. As Pease suggests vis-à-vis Joyce and Beardsley: "The irony of the attempt to bring representation closer to the body is that the representations quickly become the mediation of the body" (109). The body always remains a "discursive practice", in "serious" as well as in pornographic literature. For Pease, the "aesthetic of the obscene" thus becomes "an attempt to capture the seemingly paradoxical nature of representing the "unrepresentable" (35). Wilde's attempt to represent the unrepresentable puts him alongside other influential modernists for whom the body became the primary site for an artistic exploration of the "unknown" beyond human cognition. ${ }^{13}$ Petra Dierkes-Thun suggests that Wilde's play Salomé "prefigures modernism's central project of transforming metaphysical sublimity into physical and artistic sublimity" (Dierkes-Thun 3). While I would agree with this claim, I believe that this must be understood as a negative, apophatic sublimity, revealing the impossibility of bringing the obscene, the heterogeneous, the radically other, into the realm of representation.

The obscene is not necessarily the "realistic", explicit body in its unfiltered materiality, but rather the impossibility of appropriating this very materiality for the project of human communication, defining a fundamental limit for human subjectivity, rationality and self-mastery: "The unrepresentable-obscene-aspects of the self, then, might be seen as those impulses and drives that lie behind the sexual and excremental imagery" (Potter 102, my emphasis). All supposedly disinterested works of art depend on, as Adorno claims, "the intensity of the interest from which they are wrested" (Adorno 11). The painting of Dorian Gray literalizes this notion by recording the character's obscene acts. Yet in spite of the attempt to capture such acts, the novel ultimately suggests that they always remain fundamentally incommunicable: "Form and colour tell us of form and colour-that is all" (Wilde 2000, 111). In its claim for the autonomy of artistic representation and its concurrent exploration of the limits of such representation, Wilde's novel functions as an early example of the obscene aesthetic of modernism, disrupting the conventions of taste and morality, not because of its explicitness, but for revealing the limits of clarity, accountability and legibility, which define communal reason itself.

\section{BIBLIOGRAPHY}

Adorno, Theodor W. Aesthetic Theory. Robert Hollut-Kentor trans. London: Continuum, 1997.

Birmingham, Kevin. “The Prestige of the Law: Revisiting Obscenity Law and Judge Woolsey's ‘Ulysses’ Decision.” James Joyce Quarterly 50: 4 (2013): 991-1009.

Breuer, Rolf. "Paradox in Oscar Wilde” Irish University Review 23:2 (1993): 224-235. 
Budziak, Anna. “Oscar Wilde's Refutation of 'Depth' in The Picture of Dorian Gray: A Reading.” Brno Studies in English 30:10 (2004): 135-145.

Chisholm, Dianne. "Obscene Modernism: Eros Noir and the Profane Illumination of Djuna Barnes.” American Literature 69:1 (1997): 167-206.

Davis, Michael. "Mind and Matter in The Picture of Dorian Gray." Victorian Literature and Culture 41:3 (2013): 547-560.

Dierkes-Thrun, Petra. Salome's Modernity: Oscar Wilde and the Aesthetics of Transgression. Ann Arbor: University of Michigan Press, 2011.

Dollimore, Jonathan. Sexual Dissidence: Literatures, Histories, Theories. Oxford: Oxford University Press, 2018.

Duggan, Patrick. "The Conflict Between Aestheticism and Morality in Oscar Wilde's The Picture of Dorian Gray." WR: Journal of the Arts \& Sciences Writing Program 1:1 (2008-2009): 61-69.

Foster, Hal. “Obscene, Abject, Traumatic.” October 78 (1996): 106-124.

Freud, Sigmund. The Standard Edition of the Complete Psychological Works of Sigmund Freud, Volume XIX (1923-1925): The Ego and the Id and Other Works. James Strachey trans. London: The Hogarth Press, 1961.

Gagnier, Regenia. "Wilde and the Victorians." In The Cambridge Companion to Oscar Wilde. Ed. Peter Raby. Cambridge: Cambridge University Press, 1997.

Gillard-Estrada, Anne-Florence \& Besnault-Levita, Anne (eds.). Beyond the Victorian/Modernist Divide. Remapping the Turn-of-the-Century Break in Literature, Culture and the Visual Arts. New York: Routledge, 2018.

Goldstone, Andrew. Fictions of Autonomy: Modernism from Wilde to de Man. Oxford: Oxford University Press, 2013.

Gurfinkel, Helena. "The Second Wilde Revival: Current Trends in Oscar Wilde Scholarship." Kritikon Litterarum 43: 1-2 (2016): 143-166.

Glass, Loren. "Redeeming Value: Obscenity and Anglo-American Modernism." Critical Inquiry 32:2 (2006): 341-361.

Kant, Immanuel. Critique of Judgement. Werner S. Pluhar trans. Indianapolis: Hackett Publishing, 1987.

Lacan, Jacques. The Four Fundamental Concepts of Psychoanalysis. Alan Sheridan trans. New York: Norton, 1998.

Leckie, Barbara. "The Novel and Censorship in Late-Victorian England." In The Oxford Handbook of the Victorian Novel. Ed. Lisa Rodensly. Oxford: Oxford University Press, 2016. 166-183.

Manganiello, Dominic. "Ethics and Aesthetics in 'The Picture of Dorian Gray"' Canadian Journal of Irish Studies, 9:2 (1983): 25-33.

McGowan, John. "From Pater to Wilde to Joyce: Modernist Epiphany and the Soulful Self." Texas Studies in Literature and Language, 32:3 (1990): 417-445.

Pagnattaro, Marisa Anne. "Carving a Literary Exception: The Obscenity Standard and Ulysses". Twentieth Century Literature 47: 2 (2001): 217-240.

Pease, Allison. Modernism, Mass Culture and the Aesthetics of the Obscene. Cambridge: Cambridge University Press, 2000. 
Potter, Rachel. Obscene Modernism: Literary Censorship \& Experiment 1900-1940. Oxford: Oxford University Press, 2013.

Psomiades, Kathy Alexis. Beauty's Body: Femininity and Representation in British Aestheticism. Palo Alto: Stanford University Press, 1997.

Stern, Simon. "Wilde's Obscenity Effect: Influence and Immorality in The Picture of Dorian Gray." Review of English Studies 68 (2017): 756-772.

Wilde, Oscar. The Letters of Oscar Wilde. New York: Harcourt, Brace and World, 1962.

---.The Picture of Dorian Gray. 1891. London: Penguin, 2000.

---.The Importance of Being Earnest and Other Plays. 1898. Oxford: Oxford University Press, 2008.

---."The Soul of Man Under Socialism". In The Decay of Lying and Other Essays. 1891. London:

Penguin, 2010.

\section{NOTES}

1. “The People v. Dial Press," cited in Pagnattaro 2001, 233.

2. “The word 'obscene' is from the Latin obscenus, meaning adverse, inauspicious, ill-omened; also abominable, disgusting, filthy, indecent [...] At the same time, the word referred to ideas about the limits of representation; to those aspects of humanity or language which ought to remain offstage" (Potter 3).

3. "There were three kinds of readerships 'whose minds' were seen to be the most open to immoral influences: the young person, women and the working classes" (Potter 17).

4. The Picture of Dorian Gray, as is well known, was used against Wilde during his trial for 'gross indecency' at the Old Bailey in 1895. Following his unsuccessful libel suit against Lord Alfred Douglas' father, the Marquess of Queensbury (who had called him a "posing somdomite" (sic)), Wilde himself was twice put on trial, the second of which resulted in a conviction and a two-year prison sentence. Simon Stern suggests that the novel itself only escaped prosecution because "Wilde's trials also served in effect as an obscenity trial". During the trial, the prosecutor Charles Gill called "Dorian Gray an 'immoral and indecent work' that described the 'passions of certain persons guilty of unnatural practices,' adding that the novel was 'calculated to subvert morality and to encourage unnatural vice,' and that Wilde himself had had a 'corrupting influence' on half a dozen young men" (Stern 760).

This was reflective of the work's contemporary reception, especially in its first version, when it was published in Lippincott's Monthly Magazine in June 1890. W.E. Henley's review in the Scots Observer from 5 July 1890, for instance, claims that the novel's subject matter is "only fitted for the Criminal Investigation Department" and that Wilde does not sufficiently reject his protagonist's "course of unnatural iniquity": "Mr Wilde has brains, and art, and style; but [...] he can write for none but outlawed noblemen and perverted telegraph boys" (Wilde 2000, 218-219).

5. See Wilde's essay “The Soul of Man Under Socialism” (Wilde 2010).

6. For an in-depth analysis of the fundamental connection between the modernist creed of aesthetic autonomy and issues of class and servitude, see Goldstone 2013.

7. See for, instance, Manganiello 1983 and Breuer 1993.

8. See Sterne 2017.

9. Underlying the discourse on obscene literature, according to Pease, is the desire to police the distinction between "aesthetic" high art and "pornographic" mass culture. This desire also reflected in Wilde's portrayal of Dorian's affair with the actress Sybil Vane, who acts in a theatre for the uneducated masses where Shakespeare is played by 
"ungainly, shabbily-dressed actors" (80) to "common, rough people, with their coarse faces and brutal gestures" (79); Dorian is "rather annoyed at the idea of seeing Shakespeare done in such a wretched hole of a place" (50).

10. "I love secrecy. It seems the one thing that that can make modern life mysterious or marvellous to us" (Wilde 2000, 7).

11. See also, for instance, Wilde $2000(3,7,208,102)$.

12. See Budziak for an in-depth discussion of Wilde's deployment of the tropes of depth and surface in Dorian Gray.

13. Other notable modernist writers to have explored the paradoxical realm beyond representation include Georges Bataille, Maurice Blanchot and Samuel Beckett.

\section{ABSTRACTS}

This essay explores to what extent Wilde's novel can be considered a proto-modernist text in its adherence to an "aesthetics of obscenity" and its rejection of Kantian disinterestedness. I argue that Dorian Gray, while not explicitly describing taboo acts like modernist works such as Ulysses, is nevertheless modernist in its attempt to introduce the un-sublimated body into the realm of high art. My discussion will focus on Wilde's exploration of the tension between the body and aesthetic representation, which in the novel are symbolized by the two main characters, Dorian and Lord Henry, and literalized through the painting that records Dorian's "obscene" acts. I suggest that the text's metacommentary on the relation between obscenity and the aesthetic, between corruption and morality, makes Wilde's novel a paradigmatic modernist text. My reading of Wilde's work also analyses the nature of the obscene, which, as I argue, is not essentially the explicit representation of bodily functions or sexual acts, but the "thing" that ultimately resists representation, remaining "offstage," frustrating any attempt at appropriation and thus disrupting the basic parameters of social and subjective existence.

Cet article étudie les aspects du Portrait de Dorian Gray qui font du récit de Wilde une possible préfiguration de l'esthétique de l'obscène dans une acception moderniste; en effet, comme nombre d'œuvres modernistes, l'écriture de Wilde subvertit déjà, à sa manière, le principe de contemplation désintéressée qui est caractéristique de l'esthétique kantienne. L'article tente de montrer que ce n'est pas dans la représentation d'actions ou de gestes tabous que réside le jeu de l'écriture wildienne avec l'obscénité, mais dans sa tentative de faire entrer une corporéité non sublimée dans la sphère de l'art et de la culture noble.

\section{INDEX}

Mots-clés: modernisme, obscène, esthétique, désintéressement, rupture, corps, sublimation, pornographie, irreprésentable

Keywords: modernism, obscene, aesthetics, disinterestedness, disruption, body, sublimation, pornography, impossibility of representation 
AUTHORS

KEVIN KENNEDY

Enseignant contractuel

CY Cergy Paris Université

kevin.kennedy@cyu.fr 